\title{
Distribution, Migration and Possible Origins of Genetically Different Populations of Chum Salmon Oncorhynchus keta Along the Eastern Coasts of Northern Japan
}

\author{
Toshio Okazaki*
}

(Accepted November 29, 1985)

\begin{abstract}
Distribution and migration paths of chum salmon populations distributed in the waters northeast off Japan from autumn to spring were examined based on allelic frequencies and some biological characteristics. Two distinct maturity classes, namely maturing and immature fish were observed among autumn collections and significant allelic differences were found between them. The allelic differences of maturing fish as well as their tag recovery data indicated that maturing chum salmon population mainly consists of the fish returning to Japanese rivers.

Since immature collections taken in autumn and maturing collections taken in spring during their northward shifts were statistically very similar, it is considered that the former has a link with the latter. Allelic frequencies of these fish corresponded better with known frequencies of populations of the Amur River area in the Soviet Union. The above as well as minimal tagging data suggest that the immature fish wintered in southern waters and subsequently migrated to the north to approach the Amur River area as maturing fish.
\end{abstract}

Marine aggregations of chum salmon consist of mixtures of individuals representing diverse geographic origins and differing states of maturity. Methods that have been used in efforts to identify component populations of these mixtures have included analyses of data from tagging, scale patterns, age composition and change of CPUE..$^{1-3)}$ Whereas in recent years, the emphasis has been laid on biochemical genetic methods which offer numerous advantages for population studies through the identification of distinguishing frequencies of allelic variants of protein in different populations. ${ }^{4 ; 5)}$ The purely genetic aspects of this variation complement the predominantly environment reflection of traditional procedures used for defining structures of individual population and estimating proportions of mixed populations. The biochemical methodology has an added advantage of relative permanence of allelic frequencies in a population both among year classes (where overlap occurs) and between generations ${ }^{5,8)}$; thus baseline data are cumulative rather than requiring fresh sets of data for each generation.

However, due to the genetic complexities of a particular region, the use of genetic data alone is not sufficient to estimate the geographic origins of salmonid fishes during their pelagic phase. It is necessary to take a multifaceted approach to get reliable answer.

This report examines chum salmon, Oncorhynchus keta, populations distributed in the waters northeast off Japan through autumn to spring based on collections from 1978 to 1984 . Their migration paths and possible origins were discussed based upon gene frequency data as well as some biological characteristics.

\section{Materials and Methods}

Samples of liver, heart and muscle were taken from chum salmon collected during Japanese research cruises in waters northeast off Japan and also from the catch of the trap net fisheries on the coastal waters of the Pacific and the Okhotsk Sea in northern Japan. Sample locations are identified in Fig. 1 and sample size and dates of collection are listed in Table 1.

Research gears were gillnets and longlines. The gillnets consisted of research and commercial-type nets. Research nets consisted of 10 different mesh sizes from 48 to $157 \mathrm{~mm}$ which eliminated the fishing selectivity of gillnets of constant mesh size. ${ }^{7)}$ The same number of tans (a gillnet unit of $50 \mathrm{~m}$ length) of each mesh size were joined to one another. Commercial-type nets consisted of a

* Far Seas Fisheries Research Laboratory, Fisheries Agency of Japan, Orido, Shimizu 424, Japan (岡崎登志 夫：遠洋承産研究所). 


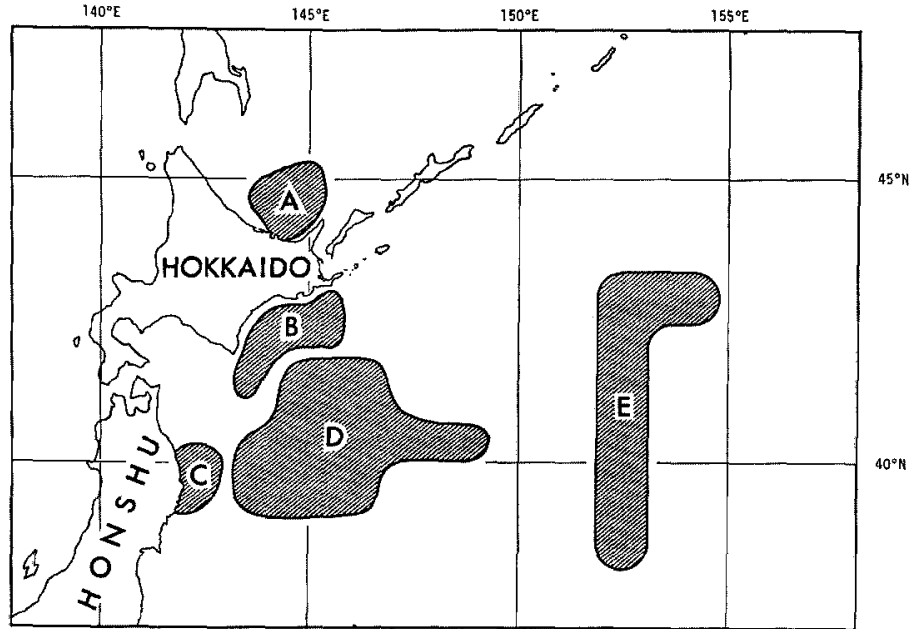

Fig. 1. Map of the waters along the eastern coasts of northern Japan showing the areas (A-E) where chum salmon were collected from 1978 to 1984 . (See also Table 1).

Table 1. Catch data of chum salmon in the waters along the eastern coasts of northern Japan in 1978-84 (See also Fig. 1)

\begin{tabular}{|c|c|c|c|c|c|c|}
\hline & \multirow{2}{*}{ Year } & \multirow{2}{*}{ Month } & \multicolumn{4}{|c|}{ Number of fish taken } \\
\hline & & & Maturing & (catch per tan) & Immature & (catch per tan) \\
\hline \multicolumn{7}{|c|}{ Autumn collections } \\
\hline \multirow{6}{*}{ Area A } & 1981 & Nov. & 338 & $(1.71)$ & 18 & $(0.12)$ \\
\hline & 1982 & Oct. & 319 & $(0.91)$ & 1 & $(0.01)$ \\
\hline & & Nov. & 184 & $(0.35)$ & 11 & $(0.03)$ \\
\hline & 1983 & Oct. & 138 & $(0.69)$ & 10 & $(0.05)$ \\
\hline & & Nov. & 100 & $(0.50)$ & 17 & $(0.09)$ \\
\hline & 1984 & Oct. & 400 & $(0.49)$ & 5 & $(0.01)$ \\
\hline \multirow[t]{10}{*}{ Area B } & 1981 & Oct. & 663 & $(2.09)$ & 12 & $(0.04)$ \\
\hline & 1982 & Aug. & 1 & $(0.01)$ & 0 & \\
\hline & & Sep. & 73 & $(0.18)$ & 0 & \\
\hline & & Oct. & 210 & $(0.52)$ & $\mathbf{0}$ & . \\
\hline & 1983 & Aug. & 88 & $(0.73)$ & 0 & \\
\hline & & Sep. & 648 & (1.44) & 3 & $(0.01)$ \\
\hline & & Oct. & 302 & $(1.51)$ & 6 & $(0.03)$ \\
\hline & 1983 & Nov.* & 67 & & 3 & \\
\hline & 1984 & Sep. & 2,745 & $(4.89)$ & 2 & $(0.01)$ \\
\hline & & Nov. & 1,092 & $(1.99)$ & 6 & $(0.01)$ \\
\hline \multirow[t]{8}{*}{ Area $\mathrm{C}$} & 1983 & Sep. & 0 & & 0 & \\
\hline & & Oct. & 80 & $(0.07)$ & 0 & \\
\hline & & Nov. & 667 & $(0.85)$ & 0 & \\
\hline & & Dec. & 113 & $(0.04)$ & 0 & \\
\hline & 1984 & Oct. & 34 & $(0.05)$ & $\mathbf{0}$ & \\
\hline & & Nov. & 728 & $(1.74)$ & 0 & \\
\hline & & Dec. & 166 & $(0.44)$ & 0 & \\
\hline & \multicolumn{6}{|c|}{ Spring collections } \\
\hline \multirow[t]{3}{*}{ Area D } & 1981 & Apr. & 88 & $(0.18)$ & 0 & \\
\hline & 1982 & Apr. & 113 & $(0.63)$ & 0 & \\
\hline & 1983 & Apr. & 173 & $(0.19)$ & 0 & \\
\hline Area E & 1978 & May & 170 & $(0.30)$ & 0 & \\
\hline
\end{tabular}


M A L E

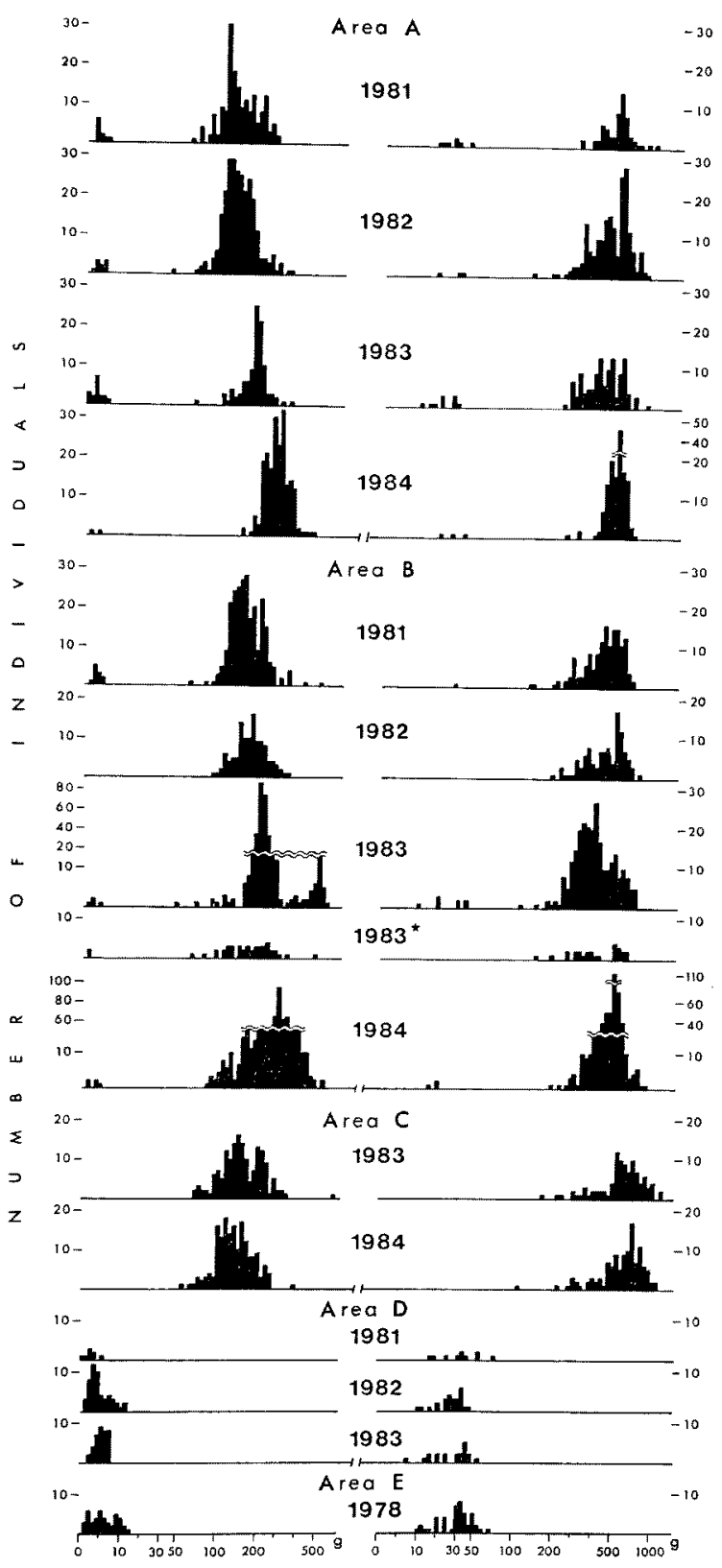

Fig. 2. Gonad weight frequency distributions of chum salmon collected in the waters along the eastern coasts of northern Japan in 1978-84. Sampling areas are identified in Fig. 1.

* Caught by longlines.

string of 27-102 tans of 112-138 mesh net. The nets used on the Kitakami-Maru and the IwateMaru consisted of five different mesh sizes from 93 to $157 \mathrm{~mm}$.
All tissues were frozen immediately following collection until processed for electrophoresis. Genetic data were collected from eight polymorphic systems. Processing of samples and 
electrophoretic methods have been described elsewhere. ${ }^{8,8)}$ Staining procedures followed methods outlined in Siciliano and Shaw. ${ }^{103}$ Nomenclature of loci and allelic variants follow those of Okazaki ${ }^{11)}$ and Beacham et al. ${ }^{\text {() }}$

\section{Results}

\section{Autumn Collections}

Since there was no actual catch in the gillnets with the mesh size of less than $82 \mathrm{~mm}$, the catch per tan of gillnets with the mesh size of 93 to 157 $\mathrm{mm}$ is shown in Table 1. Although the values of CPUE varied to a certain degree from year to year, they tended to increase as the season progressed. In the waters along the Sanriku district (area $\mathrm{C}$ in Fig. 1), the first substantial catch was observed in October. ${ }^{12,137}$ The above indicates that the fish apparently migrate southwestward to approach the coastal areas of their origin from late August to December. Such seasonal fish shifts are obviously related to their spawning migration.

Most of the fish had heavier gonad weights and were developing obvious external characteristics of imminent spawning such as nuptial coloration and hooked snouts. However, the individuals which had much lighter gonad weights $(<7 \mathrm{~g}$ in males, $<45 \mathrm{~g}$ in females) and were obvious not destined to mature and return to their natal areas during the approaching season, were included in the current collections ${ }^{14-21)}$ (Fig. 2). The two distinct maturity classes were apparent among fish of both sexes.

The actual catch as well as the mixing ratio of the immature fish in the waters along the Okhotsk coast of Hokkaido (area A) exceeded that in the waters along the Pacific coast of Hokkaido (area $B$; Table 1). The catch tended to increase as the season progressed in both areas A and B. However, no immature fish were taken through 1982's fishing season in area B. ${ }^{19)}$ None of the immature fish were collected in area $\mathrm{C}$ throughout examinations. ${ }^{12,133}$

Distribution of fork lengths of the immatures corresponded to the bottom portion of the distribution of the maturing fish in all examined populations (Fig. 3).

Ages of the fish ranged from 2 to 6 years (Table 2). As regards the ages of immature fish, since there is a limit of the number of specimens in a single year, the specimens collected throughout examinations are summed. In the maturing fish, the majority belonged to 3 to 5 -year-oids centering around 4-year-olds in all examined populations in both sexes. The age composition of immatures collected in area B was almost equal to that of the maturing fish. While, the immatures caught in area A were consisted of younger fish whose ages range from 2 to 4 in both sexes.

The allelic frequencies of each examined populations are listed in Table 3. As regards the immature fish, the specimens collected throughout examinations were summed as treated in age com-
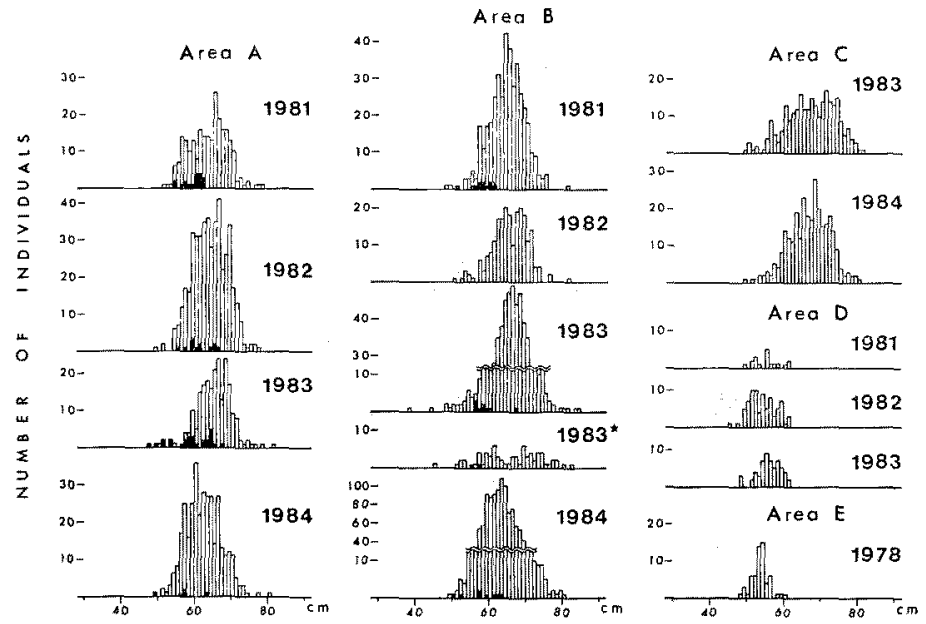

Fig. 3. Fork length frequency distributions of chum salmon collected in the waters along the eastern coasts of northern Japan in 1978-84. Shaded bars indicate immature fish. Unshaded bars indicate maturing fish.

* Caught by longlines 
Table 2. Age composition of male and female chum salmon caught in the waters along the eastern coasts of northern Japan in 1978-84 (See also Fig. 1)

\begin{tabular}{|c|c|c|c|c|c|c|c|c|c|c|c|c|c|c|c|c|c|c|}
\hline \multirow[b]{2}{*}{ Year } & \multicolumn{6}{|c|}{ Male } & \multicolumn{6}{|c|}{ Female } & \multicolumn{6}{|c|}{ Total } \\
\hline & $.1^{* 1}$ & .2 & .3 & .4 & $.5 \%)$ & $\begin{array}{l}\text { Sample } \\
\text { size }\end{array}$ & .1 & .2 & .3 & .4 & $.5(\%)$ & $\begin{array}{c}\text { Sample } \\
\text { size }\end{array}$ & .1 & .2 & .3 & .4 & $.5 \%$ & $\begin{array}{c}\text { Sample } \\
\text { size }\end{array}$ \\
\hline & \multicolumn{18}{|c|}{ Maturing (autumn collections) } \\
\hline Area A & & & & & & & & & & & & & & & & & & \\
\hline 1981 & - & 37.2 & 59.1 & 3.6 & - & 137 & - & 8.2 & 86.9 & 4.9 & - & 61 & - & 28.3 & 67.7 & 4.0 & - & 198 \\
\hline 1982 & - & 43.4 & 52.0 & 4.5 & - & 244 & - & 17.9 & 75.8 & 6.3 & - & 190 & - & 32.3 & 62.4 & 5.3 & - & 434 \\
\hline 1983 & - & 16.3 & 82.7 & 1.0 & - & 98 & - & 4.4 & 91.2 & 3.5 & 0.9 & 114 & - & 9.9 & 87.3 & 2.4 & 0.5 & 212 \\
\hline 1984 & 0.5 & 22.0 & 70.7 & 6.3 & 0.5 & 191 & - & 10.5 & 72.7 & 16.8 & - & 143 & 0.3 & 17.1 & 71.6 & 10.8 & 0.3 & 334 \\
\hline \multicolumn{19}{|l|}{ Area B } \\
\hline 1981 & 0.8 & 38.0 & 56.6 & 4.5 & - & 242 & - & 19.9 & 72.6 & 7.5 & - & 146 & 0.5 & 31.2 & 62.6 & 5.7 & - & 388 \\
\hline 1982 & 2.7 & 19.8 & 61.3 & 15.3 & 0.9 & 111 & - & 11.4 & 70.5 & 18.1 & - & 105 & 1.4 & 15.7 & 65.7 & 16.7 & 0.5 & 216 \\
\hline 1983 & 1.6 & 21.2 & 61.4 & 15.6 & 0.3 & 321 & - & 7.1 & 68.4 & 24.5 & - & 253 & 0.9 & 15.0 & 64.5 & 19.5 & 0.2 & 574 \\
\hline $1983^{* 2}$ & - & 48.8 & 46.3 & 4.9 & - & 41 & - & 33.3 & 58.3 & 8.3 & - & 24 & - & 43.1 & 50.8 & 6.2 & 一 & 65 \\
\hline 1984 & - & 25.7 & 67.7 & 6.5 & - & 672 & - & 10.9 & 77.8 & 11.3 & - & 451 & - & 19.8 & 71.8 & 8.5 & - & 1,123 \\
\hline \multicolumn{19}{|l|}{ Area C } \\
\hline 1983 & 1.9 & 26.9 & 59.6 & 11.5 & - & 156 & - & 24.0 & 56.3 & 18.8 & 1.0 & 96 & 1.2 & 25.8 & 58.3 & 14.3 & 0.4 & 252 \\
\hline 1984 & 0.6 & 11.8 & 82.9 & 4.7 & 一 & 170 & - & 13.3 & 75.2 & 11.5 & - & 113 & 0.4 & 12.4 & 79.9 & 7.4 & - & 283 \\
\hline \multicolumn{19}{|c|}{ Immature (autumn collections) } \\
\hline Area A & & & & & & & & & & & & & & & & & & \\
\hline \multicolumn{18}{|l|}{ Area B } & 59 \\
\hline $1981-84$ & 一 & 9.5 & 90.5 & - & - & 21 & - & 55.6 & 33.3 & 11.1 & - & 9 & - & 23.3 & 73.3 & 3.3 & - & 30 \\
\hline \multirow{2}{*}{\multicolumn{19}{|c|}{ Spring collections }} \\
\hline Area D & & & & & & & & & & & & & & & & & & \\
\hline 1981 & - & - & 100.0 & - & - & 8 & - & - & 33.3 & 55.6 & 11.1 & 9 & - & - & 64.7 & 29.4 & 5.9 & 17 \\
\hline 1982 & - & 2.2 & 64.4 & 33.3 & - & 45 & - & 7.7 & 65.4 & 26.9 & - & 26 & - & 4.2 & 64.8 & 31.0 & - & 71 \\
\hline 1983 & - & 2.8 & 37.5 & 58.9 & - & 36 & - & 5.0 & 40.0 & 55.0 & - & 20 & - & 3.6 & 37.5 & 58.9 & - & 56 \\
\hline \multicolumn{19}{|l|}{ Area $\mathrm{E}$} \\
\hline 1978 & - & 4.0 & 96.0 & - & - & 25 & - & 3.1 & 90.6 & 6.3 & - & 32 & - & 3.5 & 93.0 & 3.5 & - & 57 \\
\hline
\end{tabular}

*1 Numerals following a dot represent the number of winters spent in the sea. 
Table 3. Gene frequencies found at eight loci in populations of chum salmon caught in the waters along alleles were designated numbers according to the mobility relative to that of the 100 allele $\mathrm{e}^{\mathrm{s}}$

\begin{tabular}{|c|c|c|c|c|c|c|c|c|c|c|c|}
\hline \multirow[t]{2}{*}{$\begin{array}{c}\text { Sample } \\
\text { No. }\end{array}$} & \multirow[t]{2}{*}{ Area } & \multirow[t]{2}{*}{ Year } & \multirow[t]{2}{*}{$\begin{array}{c}\text { Sample } \\
\text { size }\end{array}$} & & $\begin{array}{l}\text { GDH } \\
\text { Glycer } \\
\text { iospha } \\
\text { droger }\end{array}$ & & \multicolumn{5}{|c|}{$\begin{array}{c}\text { IDH-2 } \\
\text { Isocitrate } \\
\text { dehydrogenase }\end{array}$} \\
\hline & & & & $\begin{array}{c}a \\
(100)\end{array}$ & $\begin{array}{c}b \\
(95)\end{array}$ & $\stackrel{c}{(105)}$ & $\begin{array}{c}a \\
(100)\end{array}$ & $\begin{array}{c}b \\
(40)\end{array}$ & $\begin{array}{c}c \\
(85)\end{array}$ & $\stackrel{d}{(25)}$ & $\stackrel{e}{(10)}$ \\
\hline 1. & A & 1983 & 103 & .985 & .015 & .000 & .427 & .447 & .083 & .044 & .000 \\
\hline 2. & A & 1984 & 95 & .960 & .040 & $.000 * 1$ & .505 & .342 & .047 & .100 & .005 \\
\hline 3. & B & 1982 & 42 & .976 & .024 & .000 & .441 & .357 & .048 & .155 & .000 \\
\hline 4. & B & 1983 & 292 & .997 & .003 & .000 & .572 & .329 & .014 & .084 & $.002^{* 1}$ \\
\hline $5 * 2$ & $\mathrm{~B}$ & 1983 & 67 & 1.0 & .000 & .000 & .530 & .396 & .045 & .022 & .008 \\
\hline 6. & C & 1983 & 198 & .983 & .017 & .000 & .616 & .354 & .018 & .013 & $.000^{* 1}$ \\
\hline 7. & $\mathrm{C}$ & 1984 & 260 & .983 & .013 & .004 & .600 & .335 & .021 & .044 & .000 \\
\hline 8. & A & 1983 & 18 & .719 & .281 & .000 & .583 & .250 & .139 & .028 & .000 \\
\hline 9. & $\mathrm{~B}$ & 1983,84 & 12 & .833 & .167 & .000 & .500 & .333 & .083 & .083 & .000 \\
\hline 10. & D & 1981 & 15 & .867 & .133 & .000 & .533 & .200 & .100 & .167 & .000 \\
\hline 11. & $\mathrm{D}$ & 1982 & 67 & .730 & .270 & .000 & .552 & .299 & .105 & .045 & .000 \\
\hline 12. & D & 1983 & 58 & .804 & .196 & .000 & .500 & .310 & .112 & .078 & .000 \\
\hline 13. & $E$ & 1978 & 58 & .797 & .203 & .000 & .603 & .293 & .069 & .035 & .000 \\
\hline
\end{tabular}

position. At most of the polymorphic loci, the deviation of observed number from the expectation was not significant (assuming Hardy-Weinberg equilibrium; Table 3 ). In the maturing fish, although the allelic frequencies at each locus varied to a certain degree among the collections, their values ranged within the limit of the variations of allelic frequencies of each river population in Japan. ${ }^{22)}$

However, the allelic frequencies of the immature fish were highly significant compared to those of the maturings both in area $A$ and area $B$. In particular, both immature populations possessed extremely high frequencies of the $\alpha-G d h-2-b$ allele in common. A common feature of Japanese river populations of chum salmon is the lower frequencies of this allele (usually less than $3 \%$ ). ${ }^{22}$ ) The above strongly suggest that these immature collections did not originate in Japanese rivers.

According to the tagging experiments in area $\mathrm{A}$, all of the recoveries were made along the coast of Hokkaido Island. ${ }^{15-17)}$ Similarly, all of the recoveries from tagging in areas $\mathrm{B}^{19-21)}$ and $\mathrm{C}^{12,13)}$ were made in rivers or coastal areas along the Pacific coast of Hokkaido Island and northern Honshu. The recovery rate attained as much as $40 \%$ in a certain year. The above as well as the gene frequency data strongly indicates that almost all of the maturing fish originated in Japanese rivers.

On the contrary, it seems that no recoveries of immature fish tagged in areas $A$ and $B$ have been made to date in rivers or coastal waters of Japan. This fact also supports that these immatures did not originate in Japanese rivers.

\section{Spring Collections}

Migration routes of some populations of the chum salmon occur along the eastern coast of northern Japan from April through June. These fish, so called "Tokishirazu", subsequently move northward toward the coastal waters along the Okhotsk Sea of the Soviet Union. ${ }^{23)}$ The specimens collected in spring in this study corresponded to the above populations.

Although the fish were distributed widely in the examined waters, the values of CPUE tended to be larger proceeding eastward in all years. The gonad weight frequency showed unimodal distributions in both sexes with the mode centering around $40 \mathrm{~g}$ in females and $4-6 \mathrm{~g}$ in males (Fig. 2). According to the result of Takagi, ${ }^{24)}$ these individuals would have spawned in the year they were caught. The distribution of fork lengths of the 
the eastern coasts of northern Japan. The most common allele at a locus was designated $100(a)$, and other

\begin{tabular}{|c|c|c|c|c|c|c|c|c|c|c|c|c|}
\hline & $\begin{array}{c}\text { LDH-1 } \\
\left(\begin{array}{c}\text { Lactate } \\
\text { dehydro- } \\
\text { genase }\end{array}\right)\end{array}$ & \multicolumn{3}{|c|}{$\begin{array}{c}\text { MDH-3,4 } \\
\text { Malate } \\
\text { dehydrogenase }\end{array}$} & \multicolumn{2}{|c|}{$\left.\begin{array}{c}\text { 6-PGD } \\
\text { 6-Phos- } \\
\text { phoglu- } \\
\text { conate } \\
\text { dehydro- } \\
\text { genase }\end{array}\right)$} & \multicolumn{3}{|c|}{$\begin{array}{c}\text { PGI-3 } \\
\left(\begin{array}{c}\text { Phospho- } \\
\text { glucose } \\
\text { isomerase }\end{array}\right)\end{array}$} & \multicolumn{3}{|c|}{$\begin{array}{c}\text { PMI } \\
\left(\begin{array}{c}\text { Phospho- } \\
\text { mannose } \\
\text { isomerase }\end{array}\right)\end{array}$} \\
\hline$\stackrel{a}{(100)}$ & $\begin{array}{c}b \\
(500)\end{array}$ & $\begin{array}{c}a \\
(100)\end{array}$ & $\stackrel{b}{(70)}$ & $\stackrel{c}{(120)}$ & $\begin{array}{c}a \\
(100)\end{array}$ & $\begin{array}{c}b \\
(90)\end{array}$ & $\stackrel{a}{(100)}$ & $\begin{array}{c}b \\
(90)\end{array}$ & $\stackrel{c}{(110)}$ & $\stackrel{a}{(100)}$ & $\stackrel{b}{(90)}$ & $\stackrel{c}{(110)}$ \\
\hline \multicolumn{13}{|c|}{ Maturing (autumn collections) } \\
\hline .922 & .078 & .984 & .016 & .000 & .981 & .019 & .995 & .000 & .005 & .981 & .019 & .000 \\
\hline .911 & .089 & .990 & .008 & .003 & .974 & .026 & 1.0 & .000 & .000 & .985 & .015 & .000 \\
\hline .878 & .122 & .951 & .037 & .012 & .987 & .013 & 1.0 & .000 & .000 & .951 & .037 & .012 \\
\hline .931 & .070 & .985 & .015 & .000 & .992 & .009 & .998 & .002 & .000 & .983 & .017 & $.000 * 1$ \\
\hline .946 & .055 & .985 & .010 & .005 & 1.0 & .000 & 1.0 & .000 & .000 & .971 & .029 & $.000^{* 1}$ \\
\hline .862 & .138 & .987 & .012 & .002 & .977 & .023 & 1.0 & .000 & .000 & .949 & .052 & $.000^{* 1}$ \\
\hline .870 & $.131^{* 1}$ & .991 & .009 & .000 & .996 & .004 & 1.0 & .000 & .000 & .948 & .052 & .000 \\
\hline \multicolumn{13}{|c|}{ Immature (autumn collections) } \\
\hline .972 & .028 & .984 & .000 & .016 & 1.0 & .000 & 1.0 & .000 & .000 & .917 & .056 & .028 \\
\hline .955 & .046 & .979 & .021 & .000 & 1.0 & .000 & 1.0 & .000 & .000 & .917 & .083 & .000 \\
\hline \multicolumn{13}{|c|}{ Spring collections } \\
\hline .967 & .033 & .995 & .000 & .004 & 1.0 & .000 & 1.0 & .000 & .000 & .967 & .033 & .000 \\
\hline .952 & .048 & .986 & .000 & .014 & 1.0 & .000 & 1.0 & .000 & .000 & .910 & .090 & .000 \\
\hline .926 & .074 & .964 & .000 & .036 & 1.0 & .000 & 1.0 & .000 & .000 & .983 & .009 & .009 \\
\hline .966 & .035 & .992 & .000 & .009 & .975 & .025 & 1.0 & .000 & .000 & .907 & .085 & .009 \\
\hline
\end{tabular}

*2 Caught by longlines.

fish was smaller than that of the maturing populations collected in autumn, but their distribution was almost equal to that of the immature collections in autumn (Fig. 3). Although ages of the fish ranged from 3 to 6 years, their composition varied among collections (Table 2). In most collections, 4-year-olds and 5-year-olds were most numerous, followed by 3-year-olds.

As regards the genotypic frequencies at all the polymorphic loci, no significant deviation from Hardy-Weinberg distributions were observed (Table 3). It is noteworthy that all of the spring collections were also typified by extremely high frequencies of the $\alpha-G d h-2-b$ allele as observed in the immatures of the autumn collections. The gene frequency data as well as the earlier tagging data $^{23)}$ strongly indicate that these individuals did not originate in Japanese rivers.

\section{Genetic Relationships among Collections}

In the following section, genetic relationships among collections were examined. Within the populations of the immature and spring collections, significant differences were merely observed in four combinations out of 120 combinations at examined eight loci (it was assumed that variants of duplicated loci (MDH-3,4) occurred at an equal frequency at both loci; Table 4). Within the maturing collections in autumn, 46 combinations out of 168 were significant. On the contrary, highly significant differences (149 out of 336) were observed between the maturing collections and the spring and immature collections. Furthermore, the greater part of them were significant at the $1 \%$ level.

$\mathrm{Nei}^{2} \mathrm{~s}^{25}$ genetic distance among 13 examined populations was calculated using eight loci. A resulting dendrogram (unweighted pair-group method) ${ }^{26)}$ clearly indicates two independent clusters (Fig. 4). The immature collections in autumn and spring collections show strong similarity and furthermore they are clearly distinguished from the maturing collections.

In result, the autumn immature collections and the spring collections shared a highly genetic similarity according to the gene frequency data.

\section{Discussion}

Besides the coastal waters of Hokkaido Island, chum salmon populations of two distinct maturing classes were also distributed in the waters near the southern Kuril Islands in autumn, and that significant differences in the distribution of the 
Table 4. The result of $t$-tests comparing the variations at eight loci among thirteen populations of chum salmon. A $(\star)$ indicates significant differences at one locus at $P<0.05 ;$ a $(\Theta)$ indicates significant differences at one locus at $P<0.01$. Sample numbers correspond to those in Table 3

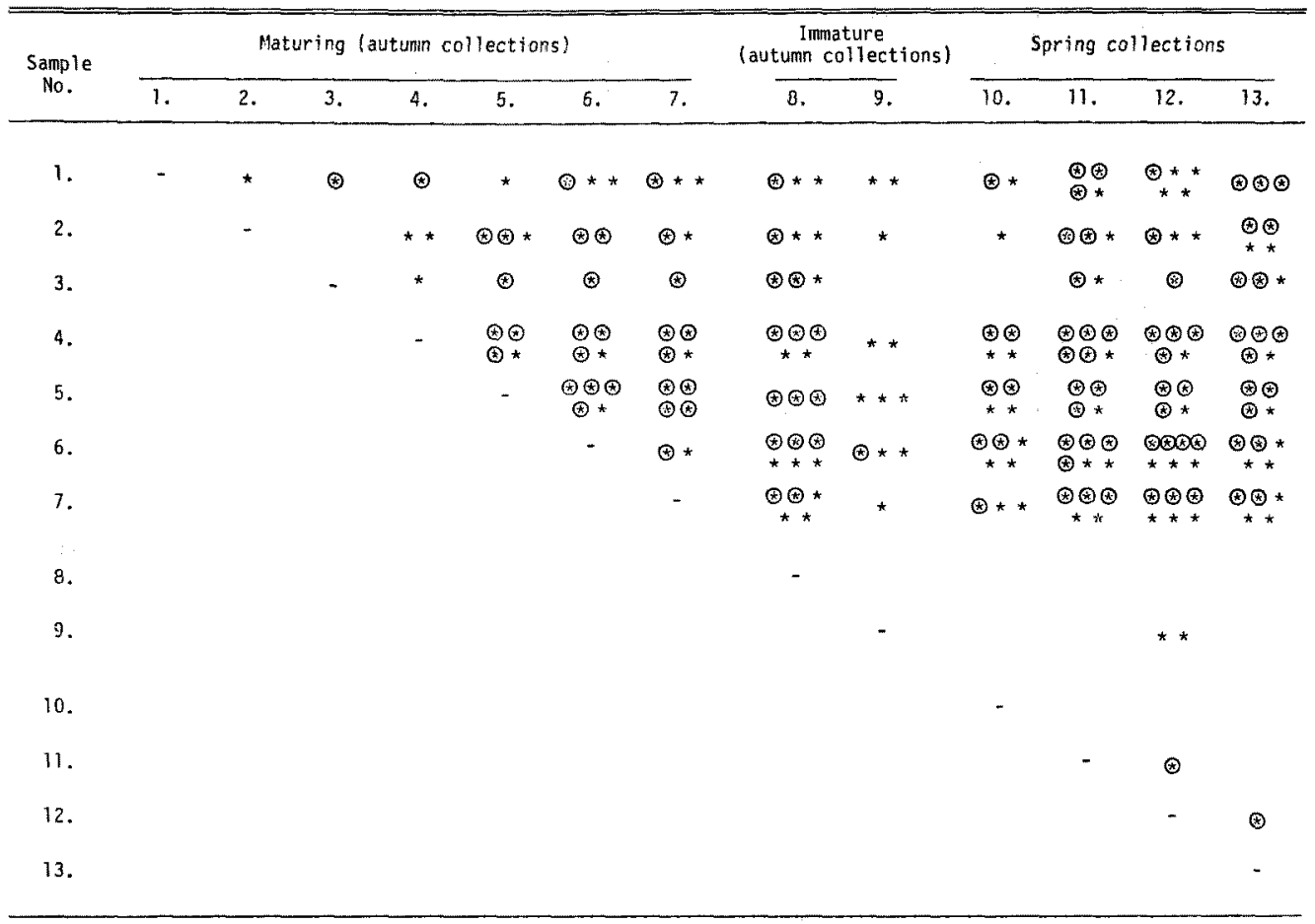

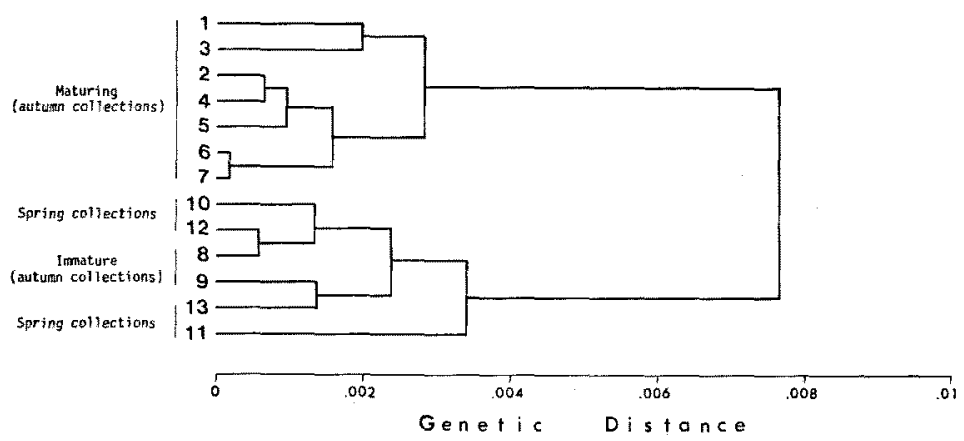

Fig. 4. Dendrogram drawn from indices of genetic distance among thirteen populations of chum salmon collected in the waters along the eastern coasts of northern Japan. Sample numbers correspond to those in Table 3.

IDH-2 alleles were observed between them. ${ }^{27)}$ On the basis of gene frequency data and the information from tag recoveries, Okazaki ${ }^{27)}$ proposed that almost all of the maturing population return to Japanese rivers within the next few months.

On the other hand, both the electrophoretic and the tagging data suggested that the immature fish originate in the Amur River area in the Soviet Union. ${ }^{27)}$ According to the minimal tagging data, ${ }^{28)}$ it was presumed that the immature fish would have migrated farther south to their wintering area and subsequently moved northward to approach coastal areas of their origin in the following spring and summer. The immature chum 
are broadly distributed in the Okhotsk Sea during the summer and begin moving southward in September as the surface waters begin to cool. ${ }^{28)}$ It is presumed that the immature population taken off the southern Kuril Islands contained fish involved in this migration.

Both the timing of appearance and the areas of appearance suggest that the immature chum salmon in the current study are closely related to the immatures taken off the southern Kuril Islands. They are also statistically indistinguishable based on the distribution of the IDH-2 alleles $(t=0.03$ $1.31, P>.05$ ). The distribution of gonad weights and fork lengths also supports the above findings.

\section{Migration Routes of Maturings}

It is considered that the routes of spawning migration of chum salmon bound for Japan are along the Kuril Islands following late summer. Before July, they are still distributed in the region around the Aleutian Chain., ${ }^{1,3)}$ It is considered that the maturing collections taken off the southern Kuril Islands are on their way to return to Japanese rivers and that subsequently each individual heads southwestward to approach the rivers of its origin (Fig. 5). Heavier gonad weights of the fish taken off southern Kuril Islands compared to those taken near the coast of Japan also correspond to the above supposition.

Limited allelic frequency data suggest a similarity of chum salmon populations returning to the rivers of south Sakhalin and Hokkaido. ${ }^{30}$ This as well as the geographic proximity and synchrony of timing of Japanese runs and those returning to south Sakhalin suggests an intermingling of these fish in the current maturing collections, particularly the fish collected in area A. However, it seems that no recoveries of maturing fish tagged in the current study have been made to date in foreign countries.

In the current study, significant differences were observed in age composition and allelic frequencies among collections. Presumably, it is partly because the sampling areas and periods varied by year and partly because many distinct river populations were included in the collections. Particularly, it is observed that the older fish tend to appear earlier and the younger fish later when the maturing chum salmon reach inshore waters. ${ }^{31,223}$ Some of the above might cause the variation among collections.

\section{Migration Routes of Immatures}

The immature chum salmon appeared widely

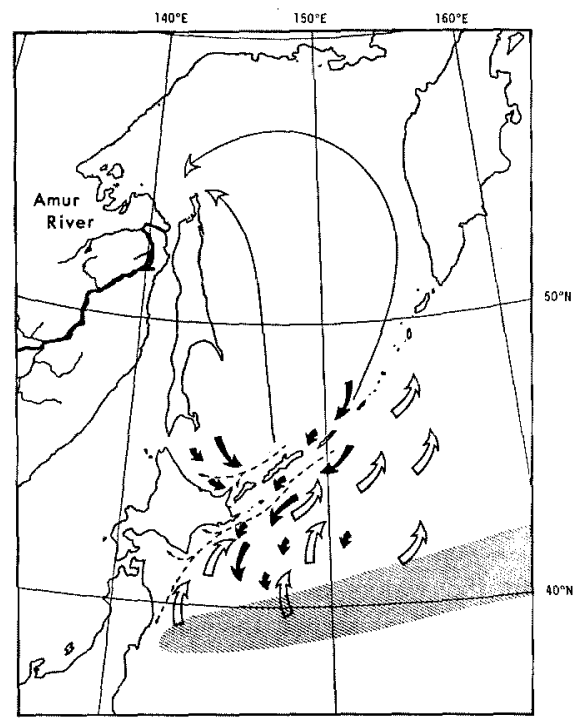

Fig. 5. Assumed migration routes of chum salmon populations in the waters along the eastern coasts of northern Japan from autumn to spring. ----; migratory routes of maturing fish from autumn to early winter. ; migratory routes of immature fish from autumn to winter, their wintering areas (shaded) and $\leftrightharpoons$; their northern migratory routes in the following spring. $₹$; migratory routes to the Amur River in the Okhotsk Sea. ${ }^{1)}$

through the examined waters in autumn. According to the change of CPUE, the abundance of the fish increased from September to November in both areas A and B. This suggests that the immature fish migrate southward as the season progresses as observed in the maturing populations. However, it seems that none of the fish migrate to the area $\mathrm{B}$ in some years. Complete lack of the immatures in the collections from area $\mathrm{C}$ indicate that their southward migration would not reach the coastal waters of northern Honshu.

In the coastal areas of Hokkaido Island, immature chum were incidentally taken by set net fisheries for maturing ones in autumn. According to S. Abe, Hokkaido Salmon Hatchery (personal communication), the fish were mainly caught in the coast facing the Okhotsk Sea in November and the catch tends to decrease proceeding southward along the coast. In the coastal areas of the Pacific, the immatures were uncommonly caught in some years in late autumn or early winter. Their body weight ranged from 2 to $3 \mathrm{~kg}$ and the scale exfoliated easily from body. 
These kinds of fish are called "Keiji" in Hokkaido. The above indicates that some portion of the immature populations migrate closely along the Okhotsk Sea coast of Hokkaido.

Although it is considered that the immature fish examined in the current study were included in the immature populations captured in the waters near the southern Kuril Islands in autumn, it is necessary to point out that more abundant fish were distributed in the area. The mixing ratio of immatures to total catch reached $24 \%$ in 1975 and $46 \%$ in $1976 .{ }^{27)}$ Therefore, the individuals analysed in this study correspond to the western segment of the entire population. Lower abundance as well as uncertain appearance in some years in the waters along the Pacific coast of Hokkaido, indicates that their main southward migration routes occur off the coastal areas. However, it was not confirmed as to how far the migration paths extend eastward from the current limited research areas.

Almost all of the immature fish presumably migrate to the north following wintering and they form a part of the chum salmon populations called "Tokishirazu" (Fig. 5). A correspondence of distribution of gonad weights and fork lengths between the autumn immature collections and the spring collections as well as the gene frequency data also supports their linkage.

It was reported that ages of chum salmon collected along the Pacific coast of Hokkaido and the southern Kuril Islands during their northward migration in late spring and early summer ranged from 3-year-olds to 5-year-olds centering around 4-year-olds. ${ }^{33}$ ) Current spring collections and immatures collected in area A corresponded to the above earlier investigation, considering that the latter would have aged when they move northward in the following year. However, limited collections of the immatures in area B consisted of older individuals. This gives a hint that older fish may precede younger fish during their southward migration in autumn as observed in spawning migration of maturing fish.

\section{Possible Origins of Immatures}

It is considered that the immature chum salmon distributed in the waters near the southern Kuril Islands in autumn are linked with the so called "Tokishirazu" in the following year. The only tag recovery of immaturely tagged fish occurred in 1977 at the mouth of the Amur River involving a fish tagged in this area in 1976. ${ }^{27}$ Earlier tagging experiments from the Pacific coastal areas of Japan in spring and early summer resulted several recoveries in the Amur River. ${ }^{23)}$ According to Okazaki, ${ }^{11,27)}$ chum salmon population of the Amur River area was typified by high frequencies of $\alpha-\mathrm{GDH}-2$ variation and relatively high frequency of the $I d h-2-c$ allele. The spring collections in the current study and the Amur River population were statistically very similar at both loci $\quad(t=0.40-1.77 \quad(\alpha$-GDH- $), \quad t=0.19-1.83$ $(\mathrm{IDH}-2) ; P>.05)$. Two lines of evidence independently suggested that these fish originated in the Amur River area.

In the Amur River, in addition to the early run which returns to the river in July, a second, somewhat later, run also returns in early and midSeptember. ${ }^{34,383}$ Generally, they are called 'summer run' and 'autumn run', respectively. Both runs are distinguished from each other by various characteristics. The later run returns to the upper and middle sections of the river in contrast to the return of the early run to the lower sections, and the later run involves a greater number of fish. ${ }^{34}$

The high seas distribution area of maturing chum bound for the Amur River in spring and early summer is located farther to the southwest than that of any other Asian stocks. ${ }^{1)}$ Although it is presumed that the distribution of both runs is highly overlapping during their pelagic phase, a clear view has not been obtained as to how far the distribution of both runs extends east and westward, or how they are mixed. Hirano ${ }^{23)}$ cited a trader's talk that numbers of fish which retained hooks in their mouths were included among the early run collected in the Amur River. They were the same hooks that fishermen used in Japanese coastal waters along the Pacific in spring and early summer. However, none of the fish in the late run retained hooks. The above suggests that the early run migrates more western waters than the late run during their northward shifts.

The standard chum salmon population of the Amur River area was obtained from the collections in late August which mainly consisted of the late run. ${ }^{11,27)}$ In the current analysis, all of the spring collections shared a strong allelic similarity with the above standard population. Furthermore, the immature populations distributed in the southern Kuril Islands also indicated a allelic similarity to the above, but a tag recovery from the immatures occurred in late July at the mouth of 
the Amur River included the peak of the early run. ${ }^{27}$ ) Although no gene frequency data exist which directly contrast these two runs, the above suggests that both have similar allelic frequencies for the examined loci.

It has been postulated that the early run returns along the eastern coast of Sakhalin while the late run returns counter clockwise around the Okhotsk Sea. ${ }^{1}$ In the current study, although it is indicated that the spring collections in the waters northeast off Japan are mainly originated from the Amur River area, a clearer view was not obtained as to the degree of difference in the distribution and migration paths between the early and late runs and how these two populations are mixed.

Supporting details for the above hypothesis for migration paths remain obscure and further data, including additional gene frequency information are needed for confirmation or modification.

\section{Acknowledgments}

Grateful acknowledgments are given to generous people for their help in collecting fish specimens; Mr. S. Nakamura of the Japan Fisheries Information Service Center; Messrs. H. Kondo, N. Nakayama, Y. Yamagishi, J. Nakata and Dr. K. Nagasawa of the Fisheries Experimental Stations of Hokkaido; Mr. Y. Ueno of the Fisheries Experimental Station of Iwate Prefecture; the crew of the research vessels. Thanks are also due to Mr. K. Katsuyama of the Japan Marine Fishery Resource Research Center for his kind help on the statistical analysis. I would like to express my sincere gratitude to Mr. S. Abe of the Hokkaido Salmon Hatchery and Mr. K. Takagi of the Far Seas Fisheries Research Laboratory, Fisheries Agency of Japan for their valuable advice and interest in the course of the work.

\section{References}

1) H. Kondo, Y. Hirano, and M. Miyake: Bull. Intern. North Pacific Fish. Comm., 17, 1-213 (1965).

2) T. Kobayashi: Sci. Rep. Hokkaido Salmon Hatchery, 16, 1-102 (1961).

3) F. Neave, T. Yonemori, and R. G. Bakkala: Bull. Intern. North Pacific Fish. Comm., 35, 1-79 (1976).

4) F. W. Allendorf and F. M. Utter: in "Fish Physiology Vol. VI" (ed. by W. S. Hoar and D. J. Randall), Academic Press, New York, 1978, pp. 407-454.
5) F. M. Utter, D. Campton, S. Grant, G. Milner, J. Seeb, and L. Wishard: in "Salmonid Ecosystems of the North Pacific" (ed. by D.C. Himsworth and W.J. McNeil), Oregon State Univ. Press, Corvalis, Oregon, 1980, pp. 285-304.

6) T. D. Beacham, R. E. Withler, and A. P. Gould: Canadian J. Fish. Aquat. Sci, 42, 437-448 (1985).

7) K. Takagi: Bull. Intern. North Pacific Fish. Comm., 32, 13-41 (1972).

8) F. M. Utter, H. O. Hodgins, and F. W. Allendorf: in "Biochemical and Biophysical Perspectives in Marine Biology Vol. I" (ed. by D. Marins), Academic Press, San Francisco, California, 1974, pp. 213-237.

9) K. Numachi: in "Shigenseibutsuron" (ed. by M. Nishiwaki), Tokyo Univ. Press, Tokyo, 1974, pp. 5-36.

10) M. J. Siciliano and C. R. Shaw: Chromatographic and Electrophoretic Techniques, Vol. 2, Heinemann, London, 1976, pp. 185-209.

11) T. Okazaki: Bull. Far Seas Fish. Res. Lab., 19, 25-116 (1982).

12) Fisheries Experimental Station of Iwate Prefecture: Report on the Experimental Fisheries of Autumn Chum Salmon in 1983, Iwate, 1984, pp. 1-32.

13) Fisheries Experimental Station of Iwate Prefecture: Report on the Experimental Fisheries of Autumn Chum Salmon in 1984, Iwate, 1986, pp. 1-46.

14) N. Nakayama, S. Tsuji, and Y. Nunokawa: Annu. Rep. Abashiri Fish. Exper. Sta., 1981, 106112 (1982).

15) N. Nakayama, H. Maruyama, K. Ohtsuki, H. Utoh, and Y. Nunokawa: Annu. Rep. Abashiri Fish. Exper. Sta., 1982, 72-82 (1983).

16) N. Nakayama, K. Ohtsuki, T. Yorita, and Y. Nunokawa: Annu. Rep. Abashiri Fish. Exper. Sta., 1983., 79-91 (1984).

17) Y. Yamagishi and K. Kuratome: Annu. Rep. Abashiri Fish. Exper. Sta., 1984, 62-71 (1985).

18) S. Nakamura and J. Ogasawara: Annu. Rep. Kushiro Fish. Exper. Sta., 1981, 143-154 (1982).

19) S. Nakamura, T. Kobayashi, K. Nagasawa, and J. Nakata: Annu. Rep. Kushiro Fish. Exper. Sta., 1982, 181-192 (1983).

20) S. Nakamura, H. Kondo, K. Nagasawa, J. Nakata, Y. Imai, and K. Hayashi: Annu. Rep. Kushiro Fish. Exper. Sta., 1983, 213-221 (1984).

21) H. Kondo, K. Nagasawa, Y. Imai, J. Nakata and Y. Yamashita: Annu. Rep. Kushiro Fish. Exper. Sta., 1984, 116-133 (1985).

22) T. Okazaki: Bull. Japan. Soc. Sci. Fish., 48, 1525-1535 (1982).

23) Y. Hirano: An Outline of the Results of the Tagging Experiments on Pacific Salmon, Hokkaido Prefectural Fish. Exper. Sta., Hokkaido, 1953, pp. 1-134. 
24) K. Takagi: Bull. Hokkaido Reg. Fish. Res. Lab., 23, 17-34 (1961).

25) M. Nei: Amer. Nat., 106, 283-292 (1972).

26) P.H. Sneath and R. R. Sokal: Numerical Taxonomy, Freeman, San Francisco, 1973, pp. 188-308.

27) T. Okazaki: Bull. Far Seas Fish. Res. Lab., 17, 141-157 (1979).

28) T. Yonemori, H. Asai, and T. Ichihara: Bull. Far Seas Fish. Res. Lab., 13, 39-61 (1975).

29) S. Mishima: Bull. Fac. Fish. Hokkaido Univ., 21, 210-226 (1970).

30) Y.P. Altukhov, E.A. Salmenkova, G.D. Ryabova, and N. I. Kulikova: Soviet J. Mar. Biol., 6, 125138 (1980).
31) J. C. Marr: Stanford Ichthyol. Bull., 2, 157-197 (1943).

32) R.S. Semko: Izvestiia Tikhookeanskogo NauchnoIssledoyatelskogo Instituta Rybnogo Khoziaistva i Okeanografii, 41, 3-109 (1954).

33) Y. Hirano: in "Anniversary Publication of Yoshimi Hirano", Hokkaido Prefectural Fish. Exper. Sta., Hokkaido, 1969, pp, 1-136.

34). S. Sano: Bull. Intern. North Pacific Fish. Comm., 18, 41-57 (1966).

35) A. G. Kaganovski: Trudy Instituta Okeanologii (Academiia Nauk SSSR), 14, (1965), (Translated from Russian by H. Sakiura; Soren Hokuyo Gyogyo Kankei Bunkenshu, 3, 15-20). 